\title{
¿Y ahora qué? \\ Impactos y resistencia social frente a la embestida ultraliberal
}

\author{
Varios Autores
}

Libros en Acción, Madrid, 2012, 232 págs.

\section{Aitana Alguacil Denche}

Socióloga, Madrid, España. Email: aitana.alguacil@gmail.com

Es ya conocida la crisis que golpea fuertemente a los países del sur de Europa, entre ellos España donde la repercusión economía, política y social se ve reflejada en los rescates bancarios y los recortes sociales, con aumentos impositivos y la privatización de la sanidad y la educación, en sus casi 6 millones de parados, en el aumento de los desahucios, etc, pero también por el descontento social visible en las continuas movilizaciones sociales y huelgas generales.

El libro que aquí se presenta está compuesto de una serie de textos urgentes que muestran la resistencia social de un país que se niega a ser azul. Respuestas diferentes a un mismo argumento que plantea la necesidad imperiosa de derribar un modelo político, económico y social que nos ha traido hasta este filo de la historia en el que convergen el colapso económico con el medioambiental y el moral.

Los estrategas del sistema se han apresurado a activar las maquinarias del miedo, con el fin de ganar tiempo, sumiendonos en la depresión colectiva. Los textos que componen este libro refuerzan dos importantes ideas: que cuando la depresión y la tristeza son llamamientos oficiales, la alegría es una forma de desobediencia, y por ello, toda forma de desobediencia tiene que reclamar para sí la alegría de su dignidad organizada y colectiva; la segunda guarda relación con la necesidad de establecer que, si la resignación ha dado como modelo us sistema que se basa en la violación de los derechos humanos de manera brutal y sistemática, y en la destrucción de un entorno del que dependemos para vivir dignamente, es preferible la peor de nuestras alternativas, a la mejor de sus resignaciones.

Los artículos de este libro estan escritos por diferentes integrantes de movimientos sociales transformadores, en los que se aportan distintos análisis sobre el momento actual en España y la respuesta social para construir un futuro diferente, urgente y necesario. Estos análisis y propuestas se desarrollan a partir de campos concretos de actuación social, agrupandose en tres bloques complementarios: 
1. Transformar en un contexto de colapso. Este bloque de tres textos se centra en el análisis sobre las causas y las consecuencias de la crisis global, partiendo de una lectura más amplia y global del sistema económico, político y social, para aterrizar con una mirada más concreta de estas causas y consecuencias del Estado español.

- La crisis global: una tormenta casi perfecta. Luis González Reyes: en este artículo nos encontramos con un análisis de la crisis en la cual se aborda la importancia del entorno para el ser humano, la crisis actual bajo una mirada histórica, la crisis de la deuda, la crisis de las clases medias, las "soluciones" míticas del capitalismo y la necesidad de un nuevo sistema.

- ¿Se ha vuelto azul la sociedad española? Un acercamiento a las posiciones políticas de una sociedad en crisis. Julio Alguacil y Aitana Alguacil: este texto realiza un análisis de las últimas elecciones generales del Estado español cuestionandose si la tener el poder político conlleva tener la hegemonía ideológica, el papel de los movimientos sociales y la movilizaciñon social., y el peso de las diferentes ideologías en la abstención política. Para ello los autores realizan un análisis electorial de todos los comicios de la democracia, analizan el papel de la abstención y el papel de los movimientos sociales en los resultados electorales.

- La quiebra de la ingeniería de Almas y valores de la indignación como principio de esperanza. José Vicente Barcia Magaz: El capitalismo, a parte de su naturaleza económica, necesita ser, de cara a perpetuarse, un poderoso inductor de realidades políticas y sociales. Para ello necesitadel condicionamiento de los gobiernos y la generación de contextos socioculturales conveninetes a partir de lo que desde el campo de la comunicación se denomina ingeniería de las almas para favorecer los objetivos de adecuación al mercado.

2. Fuerzas transversales. Este segundo bloque se compone de una serie de ejemplos en los que se observa como lo que se denominó nuevos movimientos sociales han enraizado de manera solida y estable en una realidad a la que se han sabido adaptar a través de una constante actualización de su praxis. En este sentido, se aporta una mirada muy fresca sobre el ecologismo y el ecofeminismo, el pacifismo, los movimientos altermundistas, aquellos otros que abogan por los derechos laborales o aquellos que luchan por una cultura de la libreación y no alienante.

- Crisis global: cuando el capital puso la vida a su servicio y las respuestas desde el ecologismo y la ética de los ciudadanos. Yago Herrero López: En este artículo se aborda la crisis ecológica, nada puede crecer indefinidamente en un planeta con límites, la pérdida de biodiversidad es el despilfarro de nuestro mayor seguro de vida. Analiza también la crisis social abordando la crisis de los cuidados en la sociedad urbana, la lógica de los beneficios contra la lógica de la vida, la deuda ecológica y a deuda de los cuidados. Por ultimo plantea el camino hacia la sostenibilidad, 
apoyandose en una producción ligada al mantenimiento de la vida y no a su destrucción, un cambio radical en el modelo de trabajo y igualdad y distribución de la riqueza.

- La defensa de los derechos sociales y laborales ante la acomentida ultraliberal. Paloma Monleón: Aborda elementos útiles para analizar la situación actual en España y trabakar las alternativas posibles, las polítcas de empleo, y otros entramados normativos, como los recortes en derechos sociales. Analiza el sindicalismo transformador, los movimientos sociales, el modelo de producción y la composición del tejido productivo y las tramas sociales jerarquizadas. Plantea diversas alternativas posibles al sistema actual y finaliza haciendo una defensa de los derechos sociales y laborales.

- Retos y perspectivas del antimilitarismo noviolento. Colectivo Utopía Contagiosa: tras 33 años de la aprobación de la Constitución Española vivimos en un Estado más militarista, que ha conseguido imponer el statu quo político, pero también una sociedad más desconfiada hacia las políticas militares, hacia el gasto militar... este trabajo analiza la continuiodad, refuerzo y expansión del militarismo, como práctica secreta, elitista y antidemocrática. Abordan los aspectos positivos en el antimilitarismo noviolento y propuestas de acción para el escenario actual.

- Contracultura y ciberactivismo. Derrumbando los mitos del fetichismo digital. David García Aristegui y Laura Tejado Montero: en este articulo se analiza con profundidad el uso de las nuevas tecnologías por los movimientos sociales actuales. Inicial el trabajo rompiendo el mito del origen militar de internet y señalando que la critica a esta tecnología no la podemos dejar en manos de luditas o tecnófobos. Abordan las relaciones que desde ámbitos alternativos y espacios mercantiles se dan con estas tecnologías, así como las twitter-revoluciones y (des)politización de las redes sociales.

- El mensaje transformador de la cultura popular en el siglo XXI. Valentín Ladredo: este artículo propone una reflexión sobre la cultura popular, sometida a presiones ideológicas, económicas y políticas del mercado y acuñar algunas ideas sobre las desviaciones y desplazamientos como respuesta del contrapoder que las inmensas minorías tienen. Aborda la colisión contracultural y cultura de masas, los desplazamientos y el sueño tecnodeterminista de la cultura, y la construcción de la cultura disidente en la actualidad.

3. La lucha del territorio. Este último bloque es una toma de la tierra de los principios y planteamientos que dan sentido a nuestras luchas.

- El 15-M hacia los barrios. Ángel Calle Collado: Este texto recoge un análisis sobre los orígenes del conocido Movimiento 15-M y su éxito como convocatoria social y expansión europea y mundial y su movimiento hacia el ámbito local, barrios, para explorar la democracia, buscando la 
expansión de la participación y la apropiación de los bienes políticos. Acercarlo a los barrios es acercarlo al ámbito de lo cotidiano.

- Lavapies o el arte de resolver conflictos desde la sociedad. Ana Sánchez Llorca: Articulo que narra las experiencias vividas en el barrio madrileño de Lavapiés, haciendo un rastreo por algunas de las características y experiencias que han compuesto el barrio en la última década, como forma de una genealogía material que de otra manera quedaría spultada por las transformaciones urbanas, sociales y administrativas. En este texto se analizan aspectos como habitar la dificultad de estar en el centro de la ciudad y los problemas de gentrificación, las redes de resistencia y creatividad social, vivienda y espacio público, y aborda la importancia que para este barrio han tenido los diversos centros sociales okupados que han tenido lugar en estos años.

- Defender el territorio de la cultura del ladrillazo. El caso de Murcia. Héctor Quijada Gillamón: la "cultura del ladrillazo”, la forma de denominar el modo en que la economía capitalista globalizada incide sobre nuestro territorio, en los ultimos años ha tenido una importante presencia en España, especialmente en el litoral mediterráneo, de la cual no terminamos de desprendernos y que es uno de los pilares fundamentales de la crisis que vive este país. Este texto aborda el caso de Murcia, provincia del litoral mediterráneo.

- La ciudad posible. Carlos Corominas: La demanda creciente de recursos externos por parte de las ciudades, los problemas que acarrea su escasez y las consecuencias medioambientales que su consumo genera, ponen el foco en cómo se deben articular en el futuro los ecosistemas urbanos. Este articulo analiza la resiliencia en tiempos de crisis, hace una aproximación al concepto del pico del petróleo, reflexiona sobre el desarrollo sostenible contra la regeneración, analiza el ecosistema urbano y la trampa de las smart cities, y aboga por la ciudad para la ciudadanía.

- Epílogo: ¿y ahora qué? Rodrigo Fernández Miranda: Este texto cierra el libro que aquí se introduce. Comienza planteandonos las evidencias de que el capitalismo globalizado tal y como lo veniamos conociendo empeza a entrar en una fase terminal, abordando los relatos del poder basados en las posibilidades, la austeridad y el crecimiento. Analiza el conflicto social y la indignacion como motores de transformación, así como analiza la situación tras el punto de inflexión que supuso el 15 de mayo de 2011 como forma de radicalización de la democracia. 